\title{
Political satire and its disruptive potential: irony and cynicism in Russia and the US
}

\section{Maria Brock}

To cite this article: Maria Brock (2018) Political satire and its disruptive potential: irony and cynicism in Russia and the US, Culture, Theory and Critique, 59:3, 281-298, DOI: 10.1080/14735784.2018.1496843

To link to this article: https://doi.org/10.1080/14735784.2018.1496843
(C) 2018 The Author(s). Published by Informa UK Limited, trading as Taylor \& Francis Group

曲 Published online: 25 Jul 2018.

Submit your article to this journal $\pi$

Џلll Article views: 645

View Crossmark data $\asymp$ 


\title{
Political satire and its disruptive potential: irony and cynicism in Russia and the US
}

\author{
Maria Brock \\ Centre for Baltic and East European Studies (CBEES), Södertörn University, Sweden
}

\begin{abstract}
When cynical distance and ironic posturing have become the prevalent means of relating to public life, political humour is no longer considered subversive. It has been argued that both in Russia and the United States, ideology has co-opted satire, meaning that citizens can consume outrage passively through various satirical media products, thereby displacing outrage and abstaining from more active forms of resistance. This articles explores the twenty-first century potential of irony and cynicism to disrupt and subvert through parody, be it in the form of political satire or ironic protest, examining how similar paradigms are expressed across different geographical contexts.
\end{abstract}

The ironic life is certainly a provisional answer to the problems of too much comfort, too much history and too many choices - Wampole (2013)

It has been observed that in the twenty-first century, political humour experiences difficulties gaining traction, as everyone appears to be in on the joke (Hitchens 2009), while the Internet has made sure that no topic is off limits:

These days, every politician is a laughing-stock, and the laughter which occasionally used to illuminate the dark corners of the political world with dazzling, unexpected shafts of hilarity has become an unthinking reflex on our part, a tired Pavlovian reaction to situations that are too difficult or too depressing to think about clearly. (Coe 2013)

Along similar lines, Slavoj Žižek sees certain forms of irony as indicative of a stance of 'cynical distance', and notes that 'what is really disturbing' is the 'underlying belief in the liberating, anti-totalitarian force of laughter, of ironic distance' (Žižek 1989: 24). Žižek takes his cue from Sloterdijk's description of the modern cynic and describes cynical distance from ideology as mere illusion, and a belief in being able to maintain such aloofness shows how successfully we have been coopted by ideology: 'in contemporary societies, democratic or totalitarian, that cynical distance, laughter, irony, are, so to speak, part of the game. The ruling ideology is not to be taken seriously or literally' (Žižek 1989: 24). While we may therefore cling to the idea that we have transcended false consciousness, we are in fact being duped into thinking we are free of ideological trappings merely because laughter is possible, or at times even encouraged. 
This discussion draws on the multiple layers of cynicism at work in contemporary Russia, as well as their interrelation with US and other Western instantiations of irony. The choice of the US and Russia as case studies is not accidental; each harbours modalities of political humour in response to, or as symptoms of specific political climates. If parts of American society are said to keep important questions at an ironic arm's length, then in a similar vein it is cynicism that has been treated as the ultimate Russian affliction. And while irony and cynicism may be distinct phenomena, they occupy neighbouring positions on the spectrum of 'structures of feeling'. The following discussion does not aim to provide a cultural history of either phenomenon, but looks at specific instantiations of the two, at how irony and cynicism are not only interlinked but, also, how the former can be a form of response to the latter. The aim is thus not so much to illustrate differences but, rather, to show how paradigms are expressed in different contexts. The convergence of the two contexts along certain fault lines will be thematically addressed throughout this discussion. Satire or political humour are here treated as one expression of an ironic or cynical stance to dominant political and societal formations. Indeed, it can be argued that this form of expression is a form of political communication in itself (Purcell et al. 2010). Separate from the discussion focusing on these specific geopolitical locations, the article examines the twenty-first century's apparent failure to mobilise subjectivities in the name of political or societal ideals that seek to achieve a wholesale transformation of society. The notion of such a failure coexists with, or is contradicted by, the short-lived intensity and global legacy of the Occupy movement - itself frequently employing humour in its acts of protest (e.g., Yalçıntaş 2015). The efficacy of 'ironic protest' will also be examined as it is once more becoming a common modality in responding to political developments that seem themselves to have co-opted satire, currently most visibly exemplified by US President Donald Trump's relationship with the public. Ultimately, the two phenomena emerge not as contradictions, but as responses by a generation that frequently sees political engagement as inherently flawed and traditional politics as corrupt while simultaneously facing the challenges of navigating the post-truth abundance of information circulating online.

The article analyses specific examples of satire, as well as the responses of cultural commentators and academics to these manifestations of political humour. While the approach adopted is frequently theoretical, the study draws on a number of cases in Russia, the United States and beyond that utilitise political humour in their performances or public appearances, as well as critical responses to them. An important question underpinning this article is whether there are (recent) political climates that are more conducive to political humour and satire and, more contentiously, eras during which these become more or less effective? After all, each dominant political regime produces forms of resistance, so can the same be said of the converging modalities of power in Russia and the US, among others? In order to investigate the claim that an ironic stance precludes serious engagement, the first part of this article will ask what an ironic or cynical relationship to public life entails, examining how 'living ironically' can be a manifestation of cynical ideology.

\section{Irony and cynicism in modern guises}

In the US, the archetypal contemporary ironist is represented by the hipster - a denomination few ever see fit to apply to themselves, and which is frequently treated as a kind of subspecies of the millennial, itself a generation that has become the subject of numerous 
negative myths (Thompson 2013). While there seems to be less agreement on what constitutes the essence or component parts from which hipsterdom is formed, it appears that whatever activities they partake in, be it their choice of dress, music or other forms of entertainment, hipsters do so through the prism of irony. The crux of the critique addressed at such ironists is their denial of the meaningfulness of any endeavour, including earnest participation in political life - a 'commitment phobia' to seriousness and the responsibilities this would entail:

Everything they do is ironic: from the clothes they wear to the TV-shows they watch, to the stupid facial hair they grow - it's all an endless joke. There is no substance behind any of it. Hipsters rebel against a shallow, materialistic, directionless society by being shallow, materialistic and directionless. (Greif et al. 2010: 12)

Rather than constituting a rebellion, others have argued that irony functions as a defence mechanism, becoming effective in its very slipperiness and through the self-awareness of the ironist. In the words of literary scholar Christy Wampole, 'To live ironically is to hide in public' (Wampole 2013). At the same time, Bjørn Schiermer argues that looking to hipsters as a vessel of change is an inherently futile venture, as they do not rally behind a cause as much as they define themselves via the appreciation of certain cultural objects (Schiermer 2014). However, he insists that the charge of insincerity is perhaps misdirected, even if this sincerity is mostly applied to cultural and material artefacts - indeed, behind a humorous appropriation there often lies a celebration of authenticity. Crucially, according to Schiermer, their less overtly political stance may also be connected to their privilege, as 'hipsters are young, white and middle class, typically between 20 and 35 years old' (2014: 170).

Yet there are also consistent voices that disagree with the diagnosis of a disaffected, ironic youth, both in the US and in Russia (Rutten 2016). 'New Sincerity' is regularly argued to have superseded 'The Age of Irony' (Fitzgerald 2012), perhaps most insistently so after the terrorist attacks of 9/11. In Russia, too, 'New Sincerity' refers to both an artistic movement as well as a more general stance currently thriving in many realms but especially on the Internet in more personalised formats such as blogs (Rutten 2016). However, this phenomenon is most likely neither a successor nor a predecessor to irony or cynical ideology as much as it may at times read like a reaction to them. Indeed, the fuzzy 'hipster' label is in fact just as applicable to the preciousness of New Sincerity and its aesthetic preoccupations and it, too, thrives on the Internet. This is to say that the purported seriousness of the hipster does not necessarily offer a greater public engagement and its concern with emotions, on the contrary, seems to signal a withdrawal into private life at the same time as any form of external engagement takes place through online petitions and responses to calls for donations to charitable initiatives rather than participation in any form of protest or activism.

The fears and anxieties projected onto millennials and their hipster brethren have become so acute that they have metamorphosed into doubts surrounding the efficacy of 'clicktivism' and whether social media activism can translate into 'real' (vs. virtual) political mobilisation (Dean 2005; Gladwell 2010; Morozov 2009). According to critics of this kind of political engagement, the medium's effects amplify an already-prevalent cynicism to such a degree that one arrives at total political passivity (White 2010). Simultaneously, social media are also at the centre of discussions around millennials' supposed constant 
need for distraction in an updated version of Neil Postman's 1986 Amusing Ourselves to Death - with humour, especially in the form of memes going 'viral', operating as a kind of lingua franca that enables those most skilful at tapping into this register to become most visible and thus most powerful. In her analysis following the 2016 presidential elections in the United States, journalist and critic Emily Nussbaum goes so far as to argue that 'we memed a President into existence' (Nussbaum 2017).

While not dismissing these insights, this article argues that a more productive turn to political humour can be figured if one does not hope to find in it a possible trigger of social change, or even of a change in attitudes. After all: 'empirical evidence on the effects of political satire consumption indicates that this media activity is decidedly neutral in terms of normative value' (Lance Holbert 2013: 311). Instead, 'jokes provide insights into how societies work - they are not social thermostats regulating and shaping human behavior, but they are social thermometers that measure, record and indicate what is going on' (Davies 1990: 9). For the purposes of this discussion, this means (a) nevertheless taking political humour seriously and (b) examining it to see what it can tell us about the political and cultural sensibilities of a specific time or regime. The next section will examine specific manifestations of cynicism in the Russian context, making a distinction between the cynicism of late Soviet Russia and the cynicism of Russia under Putin (Roudakova 2017: 168). Implicitly, it therefore argues for the importance of making such distinctions in order to 'treat cynicism as a cultural practice that might have some universal features and some that are historically and culturally specific' (Roudakova 2013: 3).

\section{From late Soviet to Putin-era cynicism}

Russia is often portrayed as steeped in multiple layers of cynicism: post-transition, postmodern and late-Soviet, each of which has impacted majority political participation in specific ways. In the twenty-first century's second decade, cynicism can appear to be the one type of discourse available to all groups of Russian society. It encompasses those in government and business as much as those far from the centres of power and wealth. In 2011, journalist Peter Pomerantsev claimed that, rather than conservative nationalism or neo-authoritarianism, the Kremlin's ultimate ideology is one of a cynical form of postmodernism incarnate in a political project: 'a world of masks and poses, colourful but empty, with little at its core but power for power's sake and the accumulation of vast wealth' (Pomerantsev 2011). The Russian 'postmodern' elite are seen to prefer irony as its stance and spectacle as its central mode of being. In anthropologist Natalia Roudakova's taxonomy of post-Soviet cynics, these individuals suffer from the 'cynicism of the friends of power', which is displayed through 'straight-talk jadedness, openly declared weariness, or tough-minded distrust of ideological proclamations' (Roudakova 2017: 162). In this reading, the battle for Russia's future is thus fought out between two opposing forces, an 'overarching, triumphant cynicism, hateful cynicism which glories in its own cynicism and thinks everything is for sale and there's no values, and an attempt at some sort of integrity' (Troitsky et al. 2013).

Sociologist Lev Gudkov also observes that Russians in general have become increasingly cynical with the hardships of a lengthy transition and its failed promises (Gudkov 2013). The immediate post-Soviet period with its numerous upheavals and deprivations is seen to have led to mass depoliticisation, that is, a deep mistrust of political involvement. Rather 
than resulting in a desire to exit this condition, he sees cynicism as being symptomatic of a stagnant society. Thus, while 'cynicism indicates the erosion of traditional value systems, the destruction of former beliefs and norms, the beginnings of deep socio-cultural changes in society' (Gudkov 2013), it cannot be regarded as heralding institutional or societal transformations. Instead it makes subjects more suspicious of any vision of change. In consequence, the language of political communication came to be perceived as hollow, as political forces from the Left to the Right, in the words of philosopher and activist Maria Chehonadskih, 'became formal operators without meaning' (Chehonadskih 2014: 201). It is in this sense that post-Soviet Russia can also be seen to have arrived at a postmodernist relativism which sees any political language as pure ideological jargon (Chehonadskih 2014).

Russian cynicism as a cultural practice which has helped to consolidate authoritarian forms of governance (Roudakova 2017: 159) is preceded by a cynicism which has its origin in the late Soviet period - and which paradoxically appeared in response to the political discourse of its time. Alexey Yurchak describes how, for the last generation to have been born in the Soviet Union, socialism itself had become immutable, a kind of monolith serving as a backdrop on which a degree of freedom of expression could be achieved (Yurchak 1997, 2006). This was made possible through a type of non-participation in official communist events - beyond one's physical presence - and the staging of a 'parallel event' accompanying it. Socialist ideology had achieved 'hegemony of representation' through its omnipresence, that is, the almost complete absence of discourses that would contest the official narrative. However, he insists that just because this seemingly endless stream of representations of the same political messages was tolerated by most citizens, one should not necessarily interpret this as a sign of any actual belief in their content. On the contrary, it merely seemed that 'no other public representation of reality within the official sphere could occur' (Yurchak 1997: 166). This uniquely coherent official sphere of representation tolerated no true resistance but, equally and paradoxically, it also tolerated no true recognition. Both political activists and dissidents were regarded by many with suspicion. After all, they insisted on engaging seriously with an ideology which was surely so meaningless, yet so foundational to reality that this would equate questioning its very nature. The solution was in effect a kind of 'pretense misrecognition' - a goingthrough-the-motions while simultaneously, and in private, exposing the regime to ridicule through jokes, or anekdoty, whose production and private dissemination grew exponentially in the 1970s and 1980s. This is 'cynical ideology' in the extreme: not only does the engagement in ideological practices largely replace the belief in them, it effectively makes such belief redundant (Žižek 1989).

\section{Political humour from perestroika to Trump}

Satire is militant irony, where moral norms are relatively clear, and standards are assumed against which the grotesque and absurd are measured - Northrop Frye (1957/2000: 223)

By the early 1980s, the political organisation of the Soviet Union had come to be seen by many of its citizens as both immutable and essentially empty. In one reading, jokes or anekdoty thereby operated as a kind of 'hidden transcript' (Scott 1990), a type of resistance that granted subjects a sense of not having been co-opted entirely by the regime. However, 
such an abyss between public and private discourse could also be interpreted as having created a certain amount of psychic tension. In a Freudian vein, Yurchak credits the joke-work people engaged in so rampantly as having been able to release or resolve some of this tension, while at the same time 'helping to sustain pretense misrecognition of the incongruous and to maintain concurrent official and parallel spheres' (Yurchak 1997: 183). This echoes aspects of Serguei Oushakine's critique of Soviet humour, where he insists that rather than offering a resolution to systemic oppression, these jokes 'provided an impromptu manual, a curious cultural guidebook to pitfalls and idiosyncrasies of socialism' (Oushakine 2011: 655). In other words, they enabled a kind of begrudging coexistence while, at the same time, frequently highlighting not so much systemic failures as personal lapses, because '[ $t$ ] he system's failures never seemed to be systemic enough and had to be publically reframed and re-dressed as imperfections or mistakes of concrete individuals and groups' (Oushakine 2011: 656). This is perhaps best illustrated through an example:

On the occasion of the anniversary of the Great October Socialist Revolution, a meeting of Party members is held in a village. The Chairman of the local Soviet gives a speech, 'Dear comrades! Let's look at the amazing achievements of our Party after the revolution. For example, here sits Maria. Who was she before? An illiterate peasant woman, she had but one dress and no shoes. And now? She is an exemplary milkmaid known over the entire region. Or look at Ivan Andreev. He was the poorest man in this village, had no horse, no cow, and even no axe. And now? He is a tractor driver, and has two pairs of shoes! Or look at Trofim Semenovich Alekseev. He was a nasty hooligan, a lowest drunkard, a dirty gadabout. Nobody trusted him even with a snowdrift in wintertime, as he would steal anything his gaze fell upon. And now he's a Secretary of the Party Committee! ${ }^{1}$

Here, socialism is credited with providing individuals with new opportunities to transform their previous circumstances, but depressingly (or hilariously), it is the most indolent and corrupt persons who end up benefitting the most. The blame is thus to be allocated not only to such a system, but even more so to the individuals who take advantage of these shortcomings. Natalia Roudakova insists that the distinction between this humour and the cynical humour of post-soviet Russia is that the former betrays a belief in the essential meaningfulness of the Soviet project, even if it faltered in much of its execution, while the latter is marked by an overabundance of cynical reason following the loss of a 'world in common' between subjects (Roudakova 2017).

Returning to the question of political humour's role, rather than paving the way for its disintegration, anekdoty were most likely a response to the Soviet Union's tensions and conflicts. While the Soviet Union was officially in existence until the end of 1991, this seems mostly to have been the result of institutional inertia. Besides more pressing structural and economic issues, there is only so much disidentification an ideological edifice can sustain, as it will gradually hollow it out from the core. This is how, in reference to Hegel, Žižek defines the 'silent weaving of the spirit' or the underground disintegration of the spiritual substance of a community (Žižek 1993), which is eventually followed by its public collapse.

\footnotetext{
${ }^{1}$ Taken from web collection of 100 Russian (chiefly Soviet-era) jokes, Last accessed 12.02.2018, http://www.johndclare.net/ Russ12_Jokes.htm
} 
The late Soviet period of perestroika did in fact produce its very own genre of political parody - stiob. In short, stiob's humour is characterised by an adherence to the form of normalised or hegemonic discourse while, by taking it to its extreme, simultaneously revealing the premise's utter absurdity. One of the most memorable examples of stiob is the promulgation of the theory that Vladimir Ilyich Lenin was a mushroom. ${ }^{2}$ In 1991, musician Sergey Kuryokhin went on the TV programme The Fifth Wheel (Пятое колесо) to expound his theory that, as Lenin and his revolutionary comrades had been great lovers and consumers of wild mushrooms, including hallucinogenic ones, their personalities had gradually become displaced by the personality of a mushroom. His segment featured interviews with mycologists and botanists, and concluded with Kuryokhin's famous claim:

I have absolutely irrefutable evidence that the October Revolution was carried out by people who for many years had been consuming certain mushrooms. And in the process of being consumed by these people, the mushrooms displaced their personality. These people were turning into mushrooms. In other words, I simply want to say that Lenin was a mushroom.

While it would not be true to say that a majority of people hearing this subscribed to this theory wholesale, a sufficiently high percentage of the public found itself confused as to the seriousness of the message for the Leningrad Committee of the Communist Party to release an official statement in response to inquiries about the truth of the claims, insisting that these were false as 'a mammal cannot be a plant'. Naturally, their engagement with these claims only served to expose them to further ridicule.

Even though the relaxed censorship regime of perestroika may have provided the conditions for the dissemination of such theories, it indirectly also enabled the further public undermining of political discourse. The highly formalised language of socialist states had led to the forms of estrangement described earlier, described by Yurchak as a 'performative shift' or turn away from literal or semantic meaning and toward performative meaning. Further similarities between the late Soviet Union and the period of mature neoliberalism in the West emerge here. In their 2010 article, Dominic Boyer and Alexey Yurchak highlight how some of the 'ironic modalities' of late socialism are becoming increasingly prevalent in other places, such as the United States. Indeed, the common binary of (post- or stillsocialist) East and capitalist West, corresponding to First and former 'Second' World, is not only geographically imprecise, it also easily leads one to overlook tendencies that transcend these (partially imagined but constitutive) differences.

While late capitalism may, for a time, have managed to withstand a degree of scrutiny due to the manner in which it has ideologically aligned itself with democratic forms of government, it can be argued that parts of the West have undergone a similar process of hypernormalisation. In his eponymous 2016 work, film maker Adam Curtis claims that this is a process that has led to political reality becoming deliberately opaque, obscuring the true locus of power, all thanks to a process of careful manipulation which leaves subjects bewildered and confused amidst an abundant yet overly similar mediascape (Curtis 2016). However, as alluded to earlier, prevalent modes of political discourse also produce their own genres of satire, specific instantiations of which are discussed in the next section.

2`Lenin was a Mushroom', Wikipedia entry, Last accessed 12.02.2018, http://en.wikipedia.org/wiki/Lenin_was_a_mushroom 


\section{Hypernormalisation and American stiob}

According to Jon Stewart, creator and former host of the Daily Show, a central function in much US news media has shifted from informing the public to performing what he calls scripted 'political theatre', displaying a similar tendency towards overformalisation and employment of empty rhetoric. A satirical response to this tendency of hypernormalisation of certain forms of discourse is a type of 'American stiob', exemplified in publications such as The Onion and McSweeney's, TV programmes such as The Daily Show and Stephen Colbert's Colbert Report, which ended its nine-year run in 2014, as well as characters such as Borat, who demonstrated how the exaggerated depiction of the post-Soviet, oriental Other can be turned against those most invested in its proliferation (Condee 2008). Like Soviet stiob, here the utmost importance is placed on remaining in character in order to evidence total identification with the discourse that is being parodied. The aim of this kind of critical intervention is to break the frame of perception and to reveal the hollowness of the form by showing its disjuncture with the message, especially as it becomes almost impossible to critique a discourse with the very discursive tools it provides, 'to get critical traction on the discursive formalisation that is part of political expertise itself' (Boyer and Yurchak 2010: 212). Indeed, this is where Yurchak locates the difference between the kind of cynical reason, or 'going through the motions', that characterises so much of contemporary Western life, according to Sloterdijk, and stiob's ironic performance of an overidentification with ideology.

However, while the hopeful may retain faith in the possibility that this performative shift will eventually reveal the hollowness of official discourse and thereby represent the beginning of substantial change, another outcome is that the public can happily move from laughing about the exploits of politicians, can indeed turn to these shows as a form of release while simultaneously and passively continuing to vote for these same politicians due to the lack of any visible alternative - if they vote at all. The famous Žižekian example of canned laughter which expresses amusement on the viewer's behalf, allowing a passive consumption of enjoyment, could be applied to this situation in which the parodic deconstructions of stiob enable the audience to experience transgressive enjoyment without any need for a more active response. With the election of Donald Trump, more and more criticisms regarding the detrimental effects of this kind of 'interpassivity' (Pfaller 2017) have been laid at the feet of comedians. As alluded to in the introduction, the crux of this critique tends to be that satire, especially parody or impersonations in their most toothless guise, in fact enable a further depoliticisation of the political field by focusing on low-hanging fruit such as the US President's more irksome mannerisms or his appearance. Some critics, such as writer Jonathan Coe, even go so far as to blame contemporary political humour for disincentivising active resistance:

It creates a welcoming space in which like-minded people can gather together and share in comfortable hilarity. The anger, the feelings of injustice they might have been suffering beforehand are gathered together, compressed and transformed into bursts of laughter, and after discharging them they feel content and satisfied. (Coe in Bremner et al. 2010)

At the same time, the ubiquitous availability of ironic humour means it has also made its way into the repertoire of conservatives and those even further to the right of the political spectrum. Hence, if satire is potentially becoming less powerful as a tool of dissent, or has 
even become an integral part of the right's communications arsenal, their opponents must now ask themselves the question posed by Nussbaum: 'How do you fight an enemy who's just kidding?' (2017).

\section{Hyperreal politics, hyperreal resistance}

With the increasing impression that 'it's all a show anyway', it becomes harder not only to subvert the forms political discourse takes, but also to know how and where to apply the levers. Contemporary life appears to be marked by a blurring of boundaries between the factual and the fictional. In this age of 'hyperrealism', the public is continuously assailed by a flood of images so all-encompassing that, according to Baudrillard, it becomes difficult for social actors to distinguish between 'concrete' reality and the hyperreality of the image (Baudrillard 1988). More importantly for the concerns of this discussion, some observers argue that what has become especially apparent since the 2016 US presidential election campaign is that this blurring of boundaries also affects the distinction between reality and satire. For many, the increasing overlap between fiction and reality, event and pseudo-event and truth and post-truth has reached its culmination in the election of a president who was previously a successful reality TV star, and who now seemingly employs those same techniques that made him successful in his political persona. As anthropologist Janine Wedel observed about American politics and political discourse in 2009: 'The idea of reality is being performed, but the reality of reality is more difficult to track and often undermined' (Wedel 2009: 81). This is perhaps the motivation for the hostility expressed by some journalists in response to Stephen Colbert and Jon Stewart's attempts to leave the confines of entertainment and cross over into politics, one noteable example here being Stephen Colbert's establishment of his own Super PAC in 2011 (Day 2013). And while some demand of satirists to stay in their lane and not blur the boundaries too much, others criticise the very same satirists for their lack of efficacy, implying there is more they could do, or to do it differently.

The bleeding of one realm into another as concurrent with hypernormalisation is something that can also be observed in contemporary Russia whose government, according to critic Gleb Napreenko, 'does not appeal to any of the dimensions of truth, neither its universality nor its subjective intimacy. Instead, it operates in the horizonless register of illusions' (Napreenko 2014, italics in original). While one way in which this is evident is the many guises of President Putin's persona (Brock 2016), another illustration of a situation in which it is increasingly difficult to distinguish between parody and political reality is the continued political success of Vladimir Zhirinovsky. Zhirinovsky, leader of the Liberal Democratic Party, is the paradigmatic cynical politician, acting as Putin's buffoonish alter ego regularly engaging in obscene or xenophobic speech. This unthinkable alternative to Putin draws 'the votes of cynics, whose sole motive was to reduce to absurdity the senseless and boring parliamentary debates' (Budraitskis 2014: 181). Thus, for example, in the midst of the Crimean crisis he called for the abolition of the letter b from the Cyrillic alphabet, as, he claimed, 'this is why they don't like us in Europe', implying that difficulties of pronounciation are of greater concern than a geopolitical crisis involving the annexation of foreign territory.

\footnotetext{
${ }^{3}$ Polit.ru, 'Zhirinovsky called for letter "ы" to become illegal', polit.ru, 12.03.2014, Last accessed 12.02.2018, http://polit.ru/ news/2014/03/12/alphabet/
} 
For those treating the Russian public sphere as a world of masks and poses, a simulacrum with nothing at its core, there is little to no hope that this cynical relation to politics can lead to political transformation. Yet this simplified picture of a mass withdrawal from the public sphere needs to be problematised. The persistent telling of political jokes in the Soviet Union was also evidence of a potential for resistance, in the sense of citizens trying to carve out a space of dissent, albeit privately - a case of critical as well as cynical distance. As discussed earlier, such jokes also hint at the fact that this space is needed in order to reaffirm a belief in societal, collective undertakings. The mass demonstrations which took place in Russia's largest cities - as well as surges of smaller-scale protests and strikes throughout the 1990s (Robertson 2010) - after parliamentary and presidential elections in 2011 and 2012 respectively and, more recently, in the spring of 2017, demonstrate a persistent dissatisfaction with the political field rather than a culture of total non-engagement (Budraitskis 2014).

Such seemingly contradictory tendencies of cynical passivity against a backdrop of political theatre on the one hand and public protest on the other, prove not only that social change is frequently hard to predict - indeed, leading scholars failed to predict the end of the Soviet Union (Cox 2009), which equally seemed to take the majority of its citizens by surprise (Yurchak 2006). More importantly, it should alert scholars to the potentialities of a state in which significant segments of the population appear to be at best harbouring ambivalent sentiments towards an existing regime, which can translate into large-scale resistance after long periods of seeming disengagement. This is especially true of so-called 'hybrid regimes' which, according to Graeme Robertson, are particularly vulnerable to pressure from street protests: 'Whereas it takes large numbers of oppositionists to create problems in elections, relatively small numbers of protesters can generate great embarrassment for the authorities and create a real political problem' (Robertson 2010: 186).

At the same time, the seeming contradiction between the large demonstrations in Russia in the 2010s and, in the space of a few years, the protest movement's virtual disappearance in the face of presidential approval ratings climbing up to a high of 89 per cent in June $2015^{4}$ following the prolonged conflict with former 'brother-nation' Ukraine, may in fact be not only the result of increased pressure from the government through arrests and ever-more restrictive laws. The cynicism that has shaped so much of the Russian people's relationship to politics may have helped to 'create an illusion of critical political agency, mitigating rather than amplifying protest dynamics, and thereby reaffirming rather than unsettling existing power relations' (Roudakova 2013: 7). In Roudakova's view, internal divisions among protesters were magnified as they subscribed to the cynical belief that each side was being 'conned' by the government. This meant that the movement ended up being critically devoid of the kind of unified front needed to gain traction in such an increasingly repressive political environment, to further translate political dissatisfaction into concrete political demands, while, at the same time, for large swathes of the population an antagonistic nationalism offered an escape from a political field dominated by cynicism or recurrent disappointments.

${ }^{4}$ According to poll conducted by Levada-Center: http://www.levada.ru/eng/ 


\section{Citizens failing to revolt}

Rather than coming full circle in this social diagnosis and concluding that cynicism can never serve as a force towards progress, one may still make the case that at the heart of some forms of cynicism and irony rests a moral core. Viewed from this angle, cynicism can become a tool to 'create the necessary distance between political subjects and oppressive circumstances - distance from which an agentive consciousness of resistance can take root' (Roudakova 2013: 7). 'Cynical distance' here represents a first step towards greater participation in the public sphere, rather than an increased withdrawal from it. In fact, both irony and cynicism can originate not so much in an inability or unwillingness to engage seriously with the world, but in a continued disappointment in 'the disgrace of how the world is, how we ourselves are, and how we might like things to be' (Bustillos 2012).

What has been perceived as a tendency towards 'narcissistic withdrawal' (Oushakine 2000: 1011) in Russians and the post-socialist world more generally (and that, crucially, applies to millenials as well) can then be reframed in some circumstances. In a more nuanced analysis of the so-called 'apathy' or political disengagement of post-socialist societies, these attitudes can in fact be said to represent a form of resistance to Western ideas of democratic progress and the normative ideas this entails. In addition, as anthropologist Jessica Greenberg has argued, framing nonparticipation as failure could be doubly problematic, as in certain readings it serves to produce 'failed subjects', thereby orientalising post-socialist subjects further: 'This language of alienation, disaffection, and retreat implies that apathy is a withdrawal from not only failed state institutions and compromised political processes but a cultural-psychological state produced by political-social contexts' (Greenberg 2010: 61).

Instead, nonparticipation can be seen as a response to changing socio-political contexts and the way that, in the post-socialist world (though not only), the domain of politics is often seen as corrupted or contaminated, as the disappointments and hardships experienced after transition meet the 'cynical distance' of (post)modernity.

While nonparticipation can be regarded as a key symptom of cynicism and acquiescence to the status quo, Greenberg insists that it can also be regarded as an ethical choice or attempt to remain a 'a moral subject' (Greenberg 2010: 63), a way of escaping 'the corrupting sphere of politics' (63), which is seen to be inhabited by the 'rich, criminal and corrupt' (56).

Returning to irony and the US, Richard Rorty defends this structure of feeling in a not dissimilar manner by emphasising its ethical nature, so that it becomes not a lack of seriousness or sincerity per se but, rather, a refusal to subscribe to one metaphysical conception of the world over another. While the ironist may have radical doubts based on the contingency of any moral or philosophical framework, Rorty insists that this hesitance to adopt any one framework is not incompatible with liberalism and opposition to forms of cruelty wherever they may occur. Irony's emphasis on self-fashioning places the onus on the individual to define such a stance in the absence of any guiding moral philosophy. At the same time, ironists are:

[...] never quite able to take themselves seriously because always aware that the terms in which they describe themselves are subject to change, always aware of the contingency and fragility of their final vocabularies, and thus of their selves. (Rorty 1989: 73) 
In the final analysis, however, Rorty claims that an overwhelming sense of irony is unlikely to spell the end of community - the example Rorty raises is that of the decline of religious faith, which has not led to the feared disintegration of liberal societies. Thus, while an ironic stance provides few of the assurances of other moral frameworks, it offers a new kind of historic sensibility. At the same time, this notion of irony as a non-destructive force - and, further along on this continuum, cynicism as a conservative societal mechanism - does not contradict the criticisms of non-engagement with which this discussion began. In fact, one may be able to discern in some instantiations of irony and cynicism a deep concern with how to take up an ethical stance, but one that may prove paralysing.

\section{Who can (afford to) laugh?}

It has in recent times become clear that claims of a complete lack of political engagement among 'millennials' need to be revised in the face of the large-scale mobilisation of the Occupy movement, a more recently reignited protest culture following the election of Donald Trump to office, as well as the recent popularity of politicians such as Jeremy Corbyn in the UK or Bernie Sanders in the US. And while the Occupy movement has been criticised for its lack of leadership or failure to translate the protests into concrete political demands (Gamson and Sifry 2013), this maximal openness and commitment to a non-partisan politics of democracy managed to attract great swathes of those suffering from a disenchantment with traditional politics referred to above. The socalled 'Movement of the Squares' (Gerbaudo 2017) was global in nature, referring to local protests in capital cities with simultaneous transnational links in countries as disparate as the US, Turkey and Russia. Crucially, these protests were largely driven by those selfsame allegedly disengaged young people. The 'multiple temporalities' that Michael Hardt speaks of in reference to these protests (Hardt 2017) thus also points to a more global convergence of political climates - as seen already herein in relation to Russia and the United States.

However, the Occupy movement's dissolution may yet serve to increase this 'cynical distance' to participatory democracy. At the same time, more recent large-scale protests in the US in response to Donald Trump's policies threatening women's reproductive rights, or his stance on climate change and scientific evidence more generally, have already attracted negative scrutiny, be it for being too broad or for investing too many resources in the crafting of life-size caricatures and witty puns rather than in the creation of a unified platform for political action (Garber 2017).

Indeed, the recent oversaturation of political satire produced online (Crittenden et al. 2011) and the seeming 'parody fatigue' it has resulted in has led to very postmodern responses: articles that mock the idea that a well crafted joke could topple the President (e.g., Loveness 2017), as well as the launch of a sister website of The Onion which now produces meta-satire, or satire of the political satire that supposedly considered itself capable of triggering regime change. ${ }^{5}$ This impatience with the kind of protest that is being engaged in demonstrates once more the recurrent sense that satire's potential efficacy has not been properly deployed - paradoxically, often by creators of satire 
themselves, with the blame apportioned to both creators and an audience deemed too apathetic, too cynical or too distracted by easy jokes.

Yet the phenomenon of activism, like that of political humour, is not monolithic. Satire and humour have always been important elements of societal critique and political protest, but they can only ever represent a subset of the 'activisms' that seek to instigate change. It is important to acknowledge that this article does not do justice to the mobilisation - both 'on the ground' and in digital spaces - that has taken place under the banner of some recent instantiations of protest culture such as \#blacklivesmatter, \#sayhername and \#metoo. These movements are an illustration of how the online sphere can also be a space of solidarity and accountability, demonstrating how digital activism needs to be considered in a situated, context-specific manner, rather than from a deterministic and mediacentric angle (Kaun and Uldam 2018). However, one important distinction from the focus of this article is that movements like Black Lives Matter and Me Too have functioned largely without recourse to humour. While the fact that they were created in response to racist and gender violence and thus brought about by very palpable pain may be part of the explanation for this, it could also point to certain forms of political humour being a white, elitist - and frequently male - prerogative. Indeed, when the feminist movement (itself frequently dominated by white, middle-class, cis women) does engage in forms of 'memefication' or 'pop feminism', thereby enabling its ideas to be widely shared, it is often accused of distilling and simplifying ideas, thus having to grapple with the ever looming specter of trivialisation and of ignoring or brushing off problematic racialised dynamics (Baer 2016).

Nonetheless, humour is not antithetical to tackling painful issues. Theresa O'Keefe (2014) argues that irony and mockery are in fact crucial tools of resistance and subversion. In her critique of the tactics of activist group FEMEN and the SlutWalk-movement she clarifies that their 'failure to inject mockery and irony into their approach means it is commonly read as repetitive of such norms rather than subversive' (O'Keefe 2014: 11). In other words, the tactics of stiob have a place in activism as well, if well deployed and communicated, by going beyond reproducing norms in acts of 'blank parody' (O'Keefe 2014: 7).

Marxist theorist Franco 'Bifo' Berardi applauds such an ironic use of protest in his appraisal of Argentinian art collective Erroristas of Grupo Etcetera who, in their performances and actions, "promote the idea of "Errorism" [as] an artistic response to the destruction of civil rights that has accompanied the War On Terror which they say is as much about "errors" as it is "terrorism"'. 6 In Berardi's reading, their symbolic actions 'are sufficient to produce a deconstructive effect over power's unanimous conformity' (Clinamen 2018). For Berardi, the only way to break through the cynicism is in fact to transcend the limits of language. However, it remains to be seen whether this hailing of political art and actionism simply transfers the fundamental issue from the realm of satire to that of art. What is more, while artists can be accused of a different kind of elitism or obscurantism, some are taking their performance into the open, to sites where art merges with protest, at times to confront the state or authorities directly. Rather than seeing satire as replacing more effective forms of protest, then, experience has shown the two to be in a close and symbiotic relationship, as what unites both political art and political humour is the importance placed on breaking frames of perception.

${ }^{6}$ The Erroristas of Etcetera', http://www.wecreatetogether.net/2013/02/27/the-erroristas-of-etcetera/ 
Such playing with symbols, so at odds with politicians' habitual discourse, is reminiscent of Peter Sloterdijk's description of the kynic who rejects official culture and ideology by confronting them with irony and sarcasm (Sloterdijk 1987). Returning to Russia, it has similarly been argued that 'cynicism can only be stemmed by kynicism, not by morality. Only a joyful kynicism of ends is never tempted to forget that life has nothing to lose except itself (Lipovetsky 2013). Russia has a long history of kynics resisting state cynicism through humorous refusals to play by the rules, including fictional characters such Ostap Bender of Ilf and Petrov's Twelve Chairs and Venichka of Erofeev's Moskva-Petushki, as well as underground artist Dmitry Prigov and, more recently, the women of Pussy Riot. Speaking of the mass protests in Russia in 2011 and 2012, Natalia Roudakova expresses hope in the return of 'parrhesia' in the Foucauldian sense. Indeed, she sees irony as the prevalent register in which to 'speak truth to power', as the cynical discourses of postSoviet Russia, followed by the aggressive nationalism of the last few years, have created a marked fear of pathos in the arena of political communication (Roudakova 2017).

\section{Conclusion}

This article has identified political modalities in Russia and the US (and, arguably, beyond) that converge along certain fault lines. These include an overabundant yet similar media environment - a tendency that the 24-hour news cycle and digitial platforms have only served to enhance, combined with a lack of trust in what is being presented in that environment, a perceived shortage of credibility of established politics, a tendency to blur the distinction between - or even merging of - politics and spectacle, culminating in the impression of having reached a 'hyperreal' state where the borders between truth and fiction have become porous or entirely absent, and a disenchantment with traditional politics, leading to both cynicism as well as a protest culture that shares some political tactics and aesthetics across geographical borders.

Ultimately, this analysis necessarily leads us to the question of where this leaves satire, and whether it can intervene at critical junctures by drawing attention to injustices and inconsistencies committed by those in power. Previously, this article outlined the existing argument that there is nothing inherently transformative about satire in the twenty-first century because ideology has co-opted satire, meaning that citizens can 'consume' outrage passively through various satirical media products. By displacing this outrage they can thus abstain from more active forms of resistance. More recent scholarship has suggested that the ubiquitous presence of humorous memes and satirical forms of expression has weakened impact of satire even further. However, the question posed herein is whether there was ever a belief in satire's ability to effect any change at all, or whether one retroactively imputes this belief to previous generations and then ends up condemning them for not realising its full potential. In actual fact, it may be naïve to assume that political satirists ever saw it within their power to topple regimes, especially when working in a top-down medium such as television (Basu 2015).

The discussion above established early on that what is at stake is not to prove the efficacy of satire in triggering change, but to illustrate how it can nevertheless have a different political effect. In Russia, against a backdrop of multiple layers of cynicism, political humour has reaffirmed its role both in the present and the past. Humour served and served as a coping mechanism: in conditions of censorship, for example, it enabled citizens 
to create and reaffirm a sense of personal distance and to carve out a place from which to articulate political critique. Stiob, the distinct genre of satire which emerged during late socialism and which mocks existing discursive traditions by reproducing them, and effectively over-performing an ideology that seemed as monolithic as reality itself, is one example of how hegemonic regimes affect the form political humour assumes. But with the increased prevalence of this type of humour being incorporated in formats that seek to offer political critique - notably in the US in shows such as The Colbert Report and The Daily Show and publications such as The Onion, together with new sites of humour production and via dissemination on the Internet - the increased visibility of political humour and a seemingly immutable ideological landscape have been read as having a correlative or even causal relationship, rather than as merely coinciding. However, it has been shown that there is no clear connection with irony and satire consumed interpassively', and action or inaction in other forms of public life, despite a seemingly decreasing faith in established politics. In fact, many commentators are still smarting from the perceived failure of the Occupy movement, leading to another form of conflation, namely from the idea of satire leading to increased passivity and 'cynical distance' in subjects, to its utilisation in forms of protest as making the latter ineffectual and mere empty gestures. This article has instead argued for treating political humour as a legimate form of political communciation, which is consumed like other forms of communication, while also offering additional, original forms of critique.

Least constructive of all may be to expose political humour to the same cynical attitude that has subsumed so much of public life. Instead, it may be useful to distinguish between different modes of cynicism. Besides the cynicism of those in power and the passive and self-indulgent cynicism of the powerless, which is nevertheless marked by an attitude of disdain, there is a cynicism of despair. Similarly, when speaking of irony, one should differentiate between the poseur and the self-conscious ironist. Indeed, in some interpretations irony can become a form of humility, demonstrating 'that we know we are not the center of the universe [...] That we can find humor in the contrast between our natural self-centeredness and our likely inconsequentiality, at any given moment' (Bustillos 2012). Significantly, these modes can persist in the same subject, activated under different circumstances.

However, as this article has highlighted, ironic and cynical forms of humour can be fuelled by a common disenchantment with traditional politics, while simultaneously asking what it is to be an ethical, political subject. A major distinction between the two is the way irony harbours a hope and belief in the possibility of joy (Berardi 2015), whereas cynicism does not. Indeed, the former can produce the kind of joy that can spill over and promote collective action (Segal 2017). However, far more dangerous than cynicism is the kind of nihilism which emerges at a time when the public sphere is treated as an illusion, truth seen as more slippery than ever and political allegiance a mere consequence of being trapped in the same 'filter bubble'. Satire, on the other hand, can inject an optimism into despair which may serve to reinvigorate the political arena.

\section{Acknowledgements}

The author wishes to thank Dr Jenny Gunnarsson-Payne, the anonymous reviewers and the Editor for their helpful comments. 


\section{Disclosure statement}

No potential conflict of interest was reported by author.

\section{Notes on contributor}

Maria Brock is a postdoctoral researcher at the Centre for Baltic and East European Studies at Södertörn University (Stockholm). Her research evaluates the psychosocial dynamics of transitional and post-transitional societies focusing on the former Eastern Bloc, and the former GDR and Russia in particular. Previous publications have reflected on subjects such as the role of negative affect in reactions to the case of Pussy Riot, or the status of memory objects and 'museums of the everyday' in the proliferation of post-socialist nostalgia.

\section{References}

Baer, Hester. 2016. 'Redoing Feminism: Digital Activism, Body Politics, and Neoliberalism'. Feminist Media Studies 16:1, 17-34.

Basu, L. 2015. 'TV Satire and Its Targets: Have I Got News for You, The Thick of It and Brass Eye'. In M. Meijer Drees and S. De Leeuw (eds), The Power of Satire. Amsterdam: John Benjamins, 207-216.

Baudrillard, J. 1988. Selected Writings. Stanford: Stanford University Press.

Berardi, F. 2015. And: Phenomenology of the End - Sensibility and Connective Mutation. South Pasadena, CA: Semiotext(e).

Boyer, D. and Yurchak, A. 2010. 'AMERICAN STIOB: Or, What Late-Socialist Aesthetics of Parody Reveal about Contemporary Political Culture in the West'. Cultural Anthropology 25:2, 179-221.

Bremmer, R., Coe, J., Jay, A., Lloyd, J. and Naughtie, J. 2010. 'Has Political Satire Gone too Far?' The Financial Times Limited. Available online at https://www.ft.com/content/5784ac84-bc50-11df8c02-00144feab49a (accessed 03 June 2018).

Brock, M. 2016. 'The Hyperrealities of Putin and Trump: Why It Is Worth Paying Attention to the Public Personas of Political Leaders'. Baltic Worlds 9:4, 83-87.

Budraitskis, I. 2014. 'The Weakest Link of Managed Democracy: How the Parliament Gave Birth to Nonparliamentary Politics'. South Atlantic Quarterly 113:1, 169-185.

Bustillos, M. 2012. 'Irony Is Wonderful, Terrific, Fantastic!'. The Awl. 22 July. Available online at http://www.theawl.com/2012/12/irony-is-wonderful-terrific-fantastic (accessed 03 June 2018).

Chehonadskih, M. 2014. 'The Class Composition of Russia's Anti-Putin Movement'. South Atlantic Quarterly 113:1, 196-209.

'Clinamen', 'Franco "Bifo" Berardi on the "Possibility of Joy": An interview'. 2018. Public Seminar. 30 January. Available online at http://www.publicseminar.org/2018/01/franco-bifo-berardi-onthe-possibility-of-joy/ (accessed 03 June 2018).

Coe, J. 2013. 'Sinking Giggling into the Sea'. London Review of Books. 18 July. Available online at http://www.lrb.co.uk/v35/n14/jonathan-coe/sinking-giggling-into-the-sea?utm_source= newsletter\&utm_medium=email\&utm_campaign $=3514 \&$ hq_e=el\&hq_m $=2608980 \& h q \_l=$ 14\&hq_v=667e131370 (accessed 03 June 2018).

Condee, N. 2008. 'Borat: Putting the Id Back in Identity Politics'. Slavic Review 67:1, 84-87.

Cox, M. 2009. 'Why Did We Get the End of the Cold War Wrong?' British Journal of Politics and International Relations 11:2, 161-176.

Crittenden, V., Hopkins, L. and Simmons, J. 2011. 'Satirists as Opinion Leaders: Is Social Media Redefining Roles?'. Journal of Public Affairs 11:3, 174-180.

Curtis, A. 2016. HyperNormalisation. Location: British Broadcasting Company.

Davies, C. 1990. Ethnic Humor Around the World: A Comparative Analysis. Bloomington, IN and Indianapolis, IN: Indiana University Press.

Day, A. 2013. 'Shifting the Conversation: Colbert's Super PAC and the Measurement of Satirical Efficacy'. International Journal of Communication 7:1, 414-429. 
Dean, J. 2005. 'Communicative Capitalism: Circulation and the Foreclosure of Politics'. Cultural Politics: An International Journal 1:1, 51-74.

Fitzgerald, Jonathan D. 2012. 'Sincerity, Not Irony, Is Our Age's New Ethos'. The Atlantic. 20 November. Available online at https:/www.theatlantic.com/entertainment/archive/2012/11/ sincerity-not-irony-is-our-ages-ethos/265466/ (accessed 03 June 2018).

Gamson, W. A. and Sifry, M. L. (eds). 2013. 'The \#Occupy Movement: An Introduction'. The Sociological Quarterly 54:2, 159-163.

Garber, M. 2017. 'Are We Having Too Much Fun?' The Atlantic. 27 April. Available online at https://www.theatlantic.com/entertainment/archive/2017/04/are-we-having-too-much-fun/ 523143/ (accessed 03 June 2018).

Gerbaudo, P. 2017. 'From Cyber-Autonomism to Cyber-Populism: An Ideological Analysis of the Evolution of Digital Activism'. tripleC: Communication, Capitalism \& Critique. Open Access Journal for a Global Sustainable Information Society 15:2, 477-489.

Gladwell, Malcolm. 2010. 'Small Change: "Why the Revolution Will Not Be tweeted". The New Yorker, 42-49.

Greenberg, J. 2010. “"There's Nothing Anyone Can Do About It”: Participation, Apathy, and "Successful" Democratic Transition in Postsocialist Serbia'. Slavic Review 69:1, 41-64.

Greif, M., Ross, K. and Tortorici, D. 2010. What Was the Hipster. New York, NY: n+1 Foundation.

Gudkov, L. 2013. 'Russian Cynicism: Symptom of a Stagnant Society'. openDemocracy, 22 October. Available online at https://www.opendemocracy.net/od-russia/lev-gudkov/russian-cynicismsymptom-of-stagnant-society (accessed 03 June 2018).

Hardt, M. 2017. 'Multiple Temporalities of the Movements'. tripleC: Communication, Capitalism \& Critique. Open Access Journal for a Global Sustainable Information Society 15:2, 390-392.

Hitchens, C. 2009. 'Cheap Laughs'. The Atlantic. Available online at http://www.theatlantic.com/ magazine/archive/2009/10/cheap-laughs/307650/ (accessed 03 June 2018).

Kaun, A. and Uldam, J. 2018. 'Digital Activism: After the Hype'. New Media and Society 20:6, 1-8. Lance Holbert, R. 2013. 'Developing a Normative Approach to Political Satire: An Empirical Perspective'. International Journal of Communication 7:1, 305-323.

Lipovetsky, M. 2013. 'The Indiscreet Charm of the Russian Cynic'. open Democracy. 24 October. Available online at https://www.opendemocracy.net/od-russia/mark-lipovetsky/indiscreetcharm-of-russian-cynic (accessed 03 June 2018).

Loveness, J. 2017. 'The is the Political Satire that Finally Stops Trump'. McSweeney's. 23 January. Available online at https://www.mcsweeneys.net/articles/this-is-the-political-satire-that-finallystops-trump (accessed 03 June 2018).

Morozov, E. 2009. 'The Brave New World of Slacktivism'. Available online at http://neteffect. foreignpolicy. com/posts/2009/05/19/the_brave_new_world_of_slacktivism (accessed 03 June 2018).

Napreenko, G. 2014. 'Back in the USSR?'. E-flux. Available online at http://www.e-flux.com/ journal/back-in-the-ussr/ (accessed 03 June 2018).

Northrop, F. 1957/2000. Anatomy of Criticism: Four Essays. Princeton, NJ: Princeton University Press.

Nussbaum, E. 2017. 'How Jokes Won The Election'. The New Yorker. 23 January. Available online at http://www.newyorker.com/magazine/2017/01/23/how-jokes-won-the-election (accessed 03 June 2018).

O’Keefe, T. 2014. 'My Body Is My Manifesto! SlutWalk, FEMEN and Femmenist Protest'. Feminist Review, 107:1, 1-19.

Oushakine, S. 2000. 'In the State of Post-Soviet Aphasia: Symbolic Development in Contemporary Russia'. Europe-Asia Studies 52:6, 991-1016.

Oushakine, S. 2011. 'Introduction: Jokes of Repression'. East European Politics and Societies 25:4, 655-657.

Pfaller, R. 2017. Interpassivity: The Aesthetics of Delegated Enjoyment. Edinburgh: Edinburgh University Press.

Pomerantsev, P. 2011. 'Putin's Rasputin', London Review of Books, 20 October. Available online at http://www.lrb.co.uk/v33/n20/peter-pomerantsev/putins-rasputin (accessed 03 June 2018). 
Postman, N. 1986. Amusing Ourselves to Death: Public Discourse in the Age of Show Business. London: Heinemann.

Purcell, D., Brown, M. S. and Gokmen, M. (2010). 'Achmed the Dead Terrorist and Humor in Popular Geopolitics'. GeoJournal 75:4, 373-385.

Roudakova, N. 2013. 'Toward an Ethnographic Study of Cynicism'. Conference presentation for American Anthropological Association Annual Meeting, 21-24 November.

Roudakova, N. 2017. Losing Pravda: Ethics and the Press in Post-Truth Russia. Cambridge: Cambridge University Press.

Robertson, G. R. 2010. The Politics of Protest in Hybrid Regimes: Managing Dissent in PostCommunist Russia. Cambridge: Cambridge University Press.

Rorty, R. 1989. Contingency, Irony and Solidarity. Cambridge: Cambridge University Press.

Rutten, E. 2016. Sincerity after Communism: A Cultural History. New Haven, CT: Yale University Press.

Schiermer, B. 2014. 'Late-Modern Hipsters: New Tendencies in Popular Culture'. Acta Sociologica $57: 2,167-181$.

Scott, J. C. 1990. Domination and the Arts of Resistance: Hidden Transcripts. New Haven, CT: Yale University Press.

Segal, L. 2017. Radical Happiness: Moments of Collective Joy. London: Verso.

Sloterdijk, P. 1987. Critique of Cynical Reason. Minneapolis: University of Minnesota Press.

Thompson, D. 2013. 'How to Write the Worst Possible Column About Millenials'. The Atlantic. 04 November. Available online at https://www.theatlantic.com/business/archive/2013/11/how-towrite-the-worst-possible-column-about-millennials/281129/?utm_source=atlfb (accessed 03 June 2018).

Troitsky, A., Pomerantsev, P. and Carroll, O. 2013. 'Talking Point: Is culture the New Politics in Russia?'. openDemocracy. 27 March. Available online at http://www.opendemocracy.net/odrussia/artemy-troitsky-peter-pomerantsev-oliver-carroll/talking-point-is-culture-new-politicsin- (accessed 03 June 2018).

Wampole, C. 2013. 'How to Live Without Irony'. New York Times. 17 November. Available online at http://opinionator.blogs.nytimes.com/2012/11/17/how-to-live-without-irony/?_php=true\&_ type=blogs\&_r=0 (accessed 12 Feburary 2018).

Wedel, J. 2009. Shadow Elite: How the World's New Power Brokers Undermine Democracy, Government, and the Free Market. New York: Basic Books.

White, M. 2010. 'Clicktivism is Ruining Leftist Activism'. The Guardian. 12 August. Available online at http://www.theguardian.com/commentisfree/2010/aug/12/clicktivism-ruining-leftistactivism (accessed 03 June 2018).

Yalçıntaş, A. (ed). 2015. Creativity and Humour in Occupy Movements: Intellectual Disobedience in Turkey and Beyond. Basingstoke: Palgrave.

Yurchak, A. 1997. 'The Cynical Reason of Late Socialism: Power, Pretense, and the Anekdot'. Public Culture 9:2, 161-188.

Yurchak, A. 2006. Everything Was Forever, Until It Was No More: The Last Soviet Generation. Princeton, NJ: Princeton University Press.

Žižek, S. 1989. The Sublime Object of Ideology. London: Verso.

Žižek, S. 1993. Tarrying with the Negative: Kant, Hegel, and the Critique of Ideology. Durham: Duke University Press. 